\title{
New record of Trichodesmium thiebautii Gomont ex Gomont (Oscillatoriales - Cyanophyta) for the continental shelf of northeastern Brazil
}

\author{
José Juarez Ferreira Monteiro' ${ }^{1}$, Enide Eskinazi Leça ${ }^{1,3}$, Maria Luise Koening² and Silvio José de Macedo²
}

Recebido em 22/11/2009. Aceito em 19/08/2010

\begin{abstract}
RESUMO - (Novo registro de Trichodesmium thiebautii Gomont ex Gomont (Oscillatoriales - Cyanophyta) para a plataforma continental do Nordeste do Brasil). Este estudo relata a primeira ocorrência de Trichodesmium thiebautii Gomont ex Gomont no litoral do Nordeste do Brasil. As amostras foram coletadas durante o período chuvoso (julho de 2005) e de estiagem (novembro de 2006), em seis estações distribuídas em dois perfis perpendiculares à costa do estado de Pernambuco ( $8^{\circ} 18^{\prime} \mathrm{S}-34^{\circ} 56^{\prime} \mathrm{W}$ e $\left.8^{\circ} 32^{\prime} \mathrm{S}-35^{\circ} 00^{\prime} \mathrm{W}\right)$. T. thiebautii foi registrada durante os dois períodos anuais e nas seis estações de coleta, formando colônias em forma de tufos ou raramente em feixes, com tricomas cilíndricos, retos, células quadráticas ou ligeiramente mais longas, largura entre 5-10 $\mu \mathrm{m}$ e altura de $3-15 \mu \mathrm{m}$.
\end{abstract}

Palavras-chave: caracteres taxonômicos, variação anual, variação espacial, Pernambuco

\begin{abstract}
New record of Trichodesmium thiebautii Gomont ex Gomont (Oscillatoriales - Cyanophyta) for the continental shelf of northeastern Brazil). This study reports the first occurrence of Trichodesmium thiebautii Gomont ex Gomont on the coast of northeastern Brazil. Samples were gathered during the rainy season (July 2005) and the dry season (November 2006) at six stations distributed along two perpendicular profiles of the coast of Pernambuco $\left(8^{\circ} 18^{\prime} \mathrm{S}-34^{\circ} 56^{\prime} \mathrm{W}\right.$ and $\left.8^{\circ} 32^{\prime} \mathrm{S}-35^{\circ} 00^{\prime} \mathrm{W}\right)$. T. thiebautii was found during both periods of the year and at the six collection stations, forming colonies in the form of clusters or more rarely, bundles, with straight cylindrical trichomes, quadratic or slightly longer cells, with widths between 5-10 $\mu \mathrm{m}$ and heights of 3-15 $\mu \mathrm{m}$. The hydrological variables presented small variations, contributing to wide distribution of the species.
\end{abstract}

Key words: taxonomic characters, annual variation, spatial variation, Pernambuco

\section{Introduction}

The genus Trichodesmium was described by Ehrenberg (1830) and later included by Kützing (1843) in the genus Oscillatoria (Vaucher ex Gomont). Montagne (1844) reestablished the genus Trichodesmium Ehrenberg, based on the formation of its typical and very different colonies of isolated Oscillatoria trichomes, with the genus being definitively accepted as a valid taxonomic entity (Komárek $\&$ Anagnostides 2005). The genus was recently confirmed using molecular methods (Orcutt et al. 2002).

These cyanophytes may occur as simple filaments, but they are normally found forming aggregate colonies with between 50 and 300 filaments/colony. They are characterized by their straight and slightly curved trichomes without sheaths, constricted or not, 6-22 $\mu \mathrm{m}$ in width, and straight, rounded or slightly capitate cell (Komárek \& Anagnostides 2005).

Based on morphological studies, Komárek \& Anagnostides (2005) recognized 11 species of Trichodesmium, nine of which are from marine environments and only two species have been reported as freshwater. The marine species are widely distributed in tropical and subtropical seas where they play an important ecological role not only as primary producers, but also due to their ability to fix atmospheric nitrogen and form massive growths, often with toxic characteristics (Capone et al. 1997).

The first time the genus Trichodesmium was mentioned in Brazilian waters was by Darwin (1834) during his expedition along the coast of Bahia, when he described the growth of T. erythraeum Ehrenberg. Years later, the same species was cited along the coast of Pernambuco, with the description of growth in areas near reef formations, and with the presence of T. erythraeum associated with the human disease called "Tamandaré Fever" (Sato et al. 1963).

Currently in Brazil, the genus is represented by the species T. erythraeum, T. hildebrandtii Gomont and $T$. thiebautii, of which T. hildebrandtii and T. erythraeum have been considered the most frequent and abundant. The occurrence of $T$. thiebautii was only reported along the southern coast of Brazil, where there are growths with toxic connotations as seen in bioassays with mollusks (Rörig et al. 1998; Gianesella-Galvão et al. 1995).

The aim of this study is to point out the occurrence and describe the morphological characteristics of T. thiebautii in northeastern Brazil, based on records from continental shelf waters in the state of Pernambuco.

\section{Material and methods}

Description of the area - the coast of the state of Pernambuco is one of the least extensive in Brazil, only $187 \mathrm{~km}$ long, stretching from $7^{\circ} 32^{\prime}-8^{\circ} 56^{\prime}$ $\mathrm{S}$ to $34^{\circ} 49^{\prime}-35^{\circ} 11^{\prime} \mathrm{W}$. The shelf is characterized by its reduced width, ranging from 35 to $42 \mathrm{~km}$, low depth, with a break in the shelf at around 50 to $60 \mathrm{~m}$, a mild drop of around $1.5 \mathrm{~m} / \mathrm{km}$, almost entirely covered with carbonate sediments, warm waters with an average temperature of $27^{\circ} \mathrm{C}$ and high salinity, between 35 and 37. Low ammonia, nitrite and phosphorus values are observed in both periods, the opposite of nitrate, which varies from $0.02 \mu \mathrm{mol} . \mathrm{L}^{-1}$ at the surface to $1.36 \mu \mathrm{mol} . \mathrm{L}^{-1}$ at a depth of $30 \mathrm{~m}$ (Macedo et al. 2004).

\footnotetext{
Universidade Federal Rural de Pernambuco, Departamento de Biologia, Recife, PE, Brazil

2 Universidade Federal de Pernambuco, Departamento de Oceanografia, Recife, PE, Brazil

3 Author for correspondence: enideleca@terra.com.br
} 
The area is located in a region of hot, humid climate, type As', according to the Köppen classification. Rainfall ranges from $1800 \mathrm{~mm}$ to $2364 \mathrm{~mm}$ per year, characterizing two annual periods: a rainy season from March to August, with monthly rainfall over $100 \mathrm{~mm}$, and a dry season from September to February, with rainfall less than $100 \mathrm{~mm}$. The continental flow does not extend more than 4 miles from the coast and it is more efficient during the rainy season. Areas further away from nutrient supplies depend on coastal currents (Macedo et al. 2004).

Collections and analyses - samples were taken in July 2005, during the rainy season, and November 2006, during the dry season, using superficial hauls with $20 \mu \mathrm{m}$ mesh nets, at six points distributed over two profiles perpendicular to the coast: Gaibú beach (Station 1 - 08 20 '22, $0^{\prime \prime}$

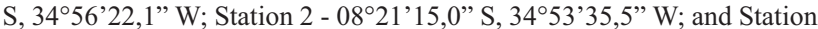
$3-08^{\circ} 21^{\prime} 38,6^{\prime \prime} \mathrm{S}, 34^{\circ} 50^{\prime} 34,2^{\prime \prime} \mathrm{W}$ ) and Serrambi beach (Station 4 -

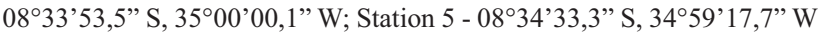
and Station $\left.6-08^{\circ} 34^{\prime} 54,8^{\prime \prime} \mathrm{S}, 34^{\circ} 54^{\prime} 42,6^{\prime \prime} \mathrm{W}\right)$. The stations were about 5,10 and 20 miles from the coast, corresponding to isobath depths of 10,20 and $30 \mathrm{~m}$. The material was immediately conserved in neutral $4 \%$ formaldehyde after collection. Cell height and width, trichome length and number of trichomes per colony were measured. Thirty measurements were taken for each variable. Species identification was based on Komárek \& Anagnostides (2005).

The results underwent analysis of variance (ANOVA) to detect significant differences between the biological variables analyzed. The Student $t$ test was applied to locate differences between collection points and rainy and dry seasons.

\section{Results}

Trichodesmium thiebautii Gomont ex Gomont was found at the six collection stations and during both periods of the year, showing that it is a common species along the coast of Pernambuco. It had homocyte trichomes, forming cluster-shaped, and rarely twisted bundle shaped colonies. Cylindrical, straight trichomes, without constriction, on average 48 per colony, were more abundant in colonies collected at Serrambi (Station 5, dry season), where colonies with up to 100 trichomes were observed. Trichome length ranged from 110 to $2,110 \mu \mathrm{m}$, being longer during the dry season. Quadratic or slightly longer cells, with widths between $5-10 \mu \mathrm{m}$ and heights between $3-15 \mu \mathrm{m}$ (Fig. 1).
Significant differences $(<0.001$, highly significant) between the height and width of cells and the size of trichomes collected at different collection points were revealed. These differences were not significant when trichomes from the same colony were considered. Highly significant differences were also detected when comparing trichomes between the two annual periods.

\section{Discussion}

In northeastern Brazil, the genus Trichodesmium was only represented by $T$. erythraeum, which has been found with dense growths that are at times harmful to the environment (Sato et al. 1963), and thus the occurrence of T. thiebautii represents an expansion of the genus into northeastern Brazil. The two species are easily separated by their morphological characteristics. While T. erythraeum has a constricted trichome on its outer wall, and a visibly capitate apical cell, in T. thiebautii the trichome has no constriction and the apical cell is rounded or slightly capitate. Furthermore, bundle-shaped colonies in T. erythraeum have trichomes arranged parallelly, whereas in T. thiebautii these colonies are slightly twisted.

The morphometric characteristics of the T. thiebautii specimens found on the Pernambuco shelf confirm Janson et al. (1995) hypothesis, showing that trichome morphology can vary from colony to colony, but the trichomes within a colony are very uniform in size and in morphology, suggesting that specimens in the same colonies are clonal.

Trichodesmium thiebautii is characterized by high productivity and capacity to assimilate atmospheric nitrogen, which is why it is one of the main producers in oligotrophic seas. Its presence and ecological importance have been confirmed in other tropical regions, and it is considered responsible for the increase in planktonic biomass (Gallon et al. 1996). The species' presence in the oligotrophic waters of northeastern Brazil confirms its preference for high-temperature sites.

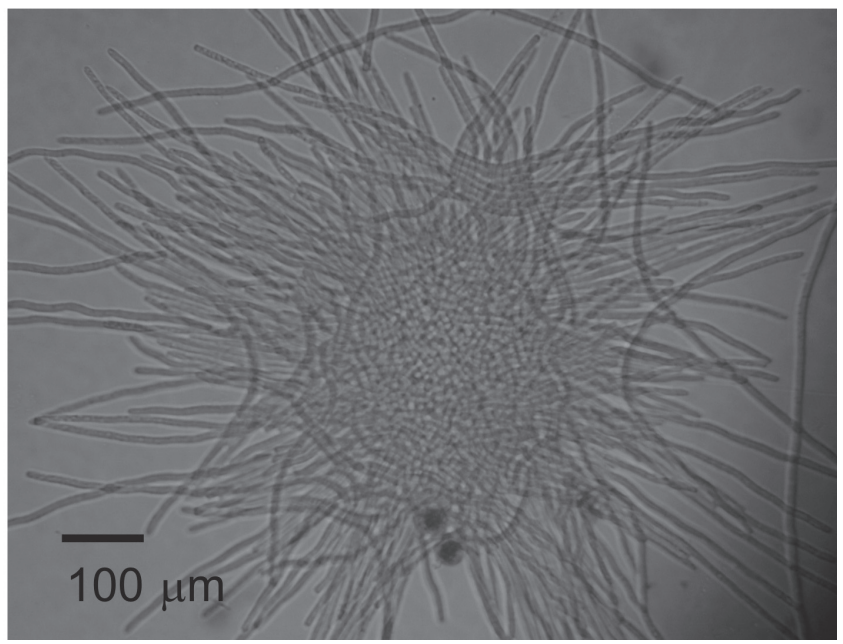

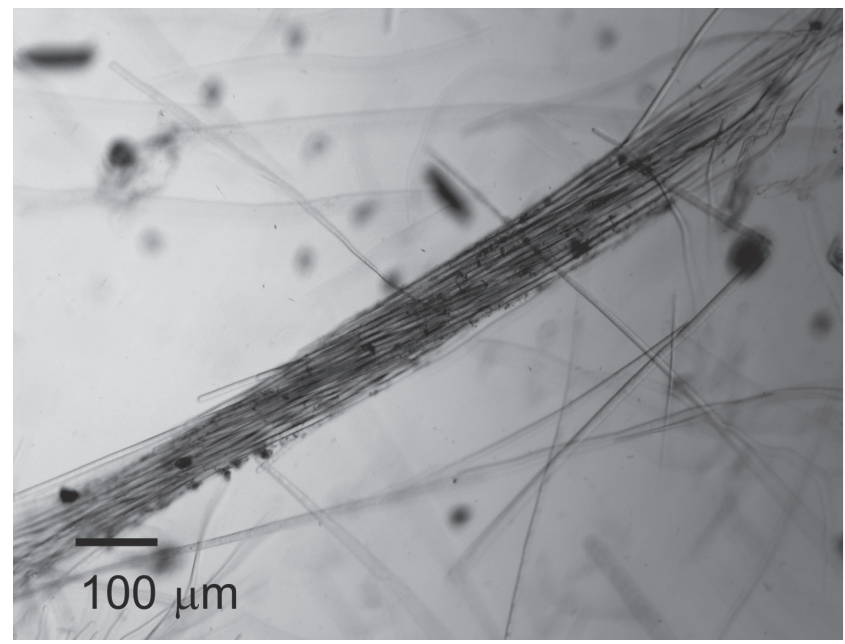

Figure 1. Trichodesmium thiebautii Gomont ex Gomont found in the Pernambuco shelf (Northeastern Brazil) 
Small morphological variations in T. thiebautii colonies found in diverse tropical environments have been related to annual environmental conditions, characterized by small variations in water temperature. According to Lugomela et al. (2002), although the species is found year round, its occurrence along the coast of Tanzania is mainly related to the rainy season, when there is a greater concentration of nutrients. According to Carpenter et al. (2004), in the tropical North Atlantic Ocean, T. thiebautii is the most common species of Trichodesmium and populations have trichomes with approximately 100 cells, and average diameters of $10 \mu \mathrm{m}$. In the Bay of Aqaba (Red Sea), Post et al. (2002) indicated the presence of $T$. thiebautii throughout the year, including growth on the surface of the water. In this bay, 45 trichomes were found per colony.

These data indicate that some environmental variables contribute more than others to the morphological variation of these specimens. Lugomela et al. (2002) reported morphological variation in species of Trichodesmium linked to high nutrient concentrations. In the areas currently under analysis, differences are more significant in cell size and number of trichomes in different colonies. There have been more robust filaments at sites farther from the coast, regardless of the two periods of the year, denoting that in the tropical waters of northeastern Brazil, Trichodesmium thiebautii specimens are better adapted to sites with less movement and lower nutrient salt content.

\section{References}

Capone, D.G.; Zehr, J.; Paerl, H.W.; Bergman, B. \& Carpenter, E.J. 1997. Trichodesmium, a globally significant marine cyanobacterium. Science 276: 1221-1229.

Carpenter, E.J.; Subramaniam, A. \& Capone, D.G. 2004. Biomass and primary productivity of the cyanobacterium Trichodesmium spp. in the tropical N Atlantic Ocean. Deep-Sea Research 51: 173-203.
Darwin, C. 1934. The beagle diary. Cambridge, Cambridge University Press.

Ehrenberg, C.G. 1830. Neue beobachtungen über blutartige Erscheinungen in aegypten, arabien und siberien. Physik und Chemie 18: 502-508.

Gallon, J.R.; Jones, D.A. \& Page, T.S. 1996. Trichodesmium, the paradoxical diazotroph. Algological Studies 83: 215-243.

Gianesella-Galvão, S.M.F; Costa, M.P.F. \& Kutner, M.B.B. 1995. Bloom de Oscillatoria (Trichodesmium) erythraeum (Ehrenberg) Kutzing in costal waters of the Southweast Atlantic. Publicação Especial do Instituto Oceanográfico 11: 133-140.

Janson, S.; Siddigui, P.J.A.; Walsby, A.E.; Romans, M.; Carpenter, E.J. \& Bergman, B. 1995. Cytomorphological characterization of the planktonic diazotrophic cyanobacteria Trichodesmium spp. from the Indian Ocean and Caribean and Sargasso Seas. Journal of Phycology 31: 463-477.

Komárek, J. \& Anagnostides, K. 2005. Cyanoprokaryota: Oscillatoriales, 2. teil. Süsswasserflora von mitteleuropa. München, Elsevier GmBH.

Kützing, T.F. 1843. Phycologia Generally Oder Anatomie, Physiologie und Systemkunde der Tange. Leipzing.

Lugomela, C.; Lyimo T.J.; Bryceson, I.; Semesi, A.K. \& Bergman, B. 2002. Trichodesmium in coastal waters of Tanzania: diversity, seasonality, nitrogen and carbon fixation. Hydrobiologia 477: 1-13.

Macedo, S.J.; Muniz, K.; \& Montes, M.J.F. 2004. Hidrologia da região costeira e plataforma do estado de Pernambuco. Pp. 255-286. In: Eskinazi-Leça. E.; Costa M.F. \& Neumann Leitão S. (eds.). Oceanografia - Um cenário tropical. Recife, Edições Bagaço.

Orcutt, K.M.; Rasmussen, U.; Webb, E.A.; Waterbury, J.B.; Gundersen, K. \& Bergmam, B. 2002. Characterization of Trichodesmium spp. by genetic techniques. Applied and Environmental Microbiology 68: 2236-2245.

Post, A.F.; Dedej, Z.; Gottlieb, R.; LI, H.; Thomas, D.N.; El-Naggar, M.A.; El-Gharabaw, M.I. \& Sommer, U. 2002. Spatial and temporal distribution of Trichodesmium spp. in the stratified Gulf of Aqaba, Red Sea. Marine Ecology 239: 241-250.

Rörig, L.R.; Yunes, J.S.; Kuroshima, K.N.; Schetinni, C.A.F.; Pezzuto, P.R. \& Proença, L.A.O. 1998. Studies on the ecology and toxicity of Trichodesmium spp. blooms in southern Brazilian coastal waters. Harmful Algae 1: 22-25.

Sato, S.; Paranaguá, M.N. \& Eskinazi, E. 1963. On the mecanism of red tide of Trichodesmium in the Recife, northeastern Brazil, with some considerations of the relation to the human disease, "Tamandaré Fever". Trabalhos do Instituto Oceanográfico da Universidade Recife 5/6: 7- 49. 